\title{
A Complementary-compensatory Approach to Teaching Focus on Form/S in EFL/ESL Classrooms
}

\author{
Mohammad Khatib \\ Allameh Tabataba'i University, Tehran, Iran \\ Email: mkhatib27@yahoo.com \\ Ali Derakhshan \\ Allameh Tabataba'i University, Tehran, Iran \\ Email: aderakhshanh@gmail.com
}

\begin{abstract}
Focus on form has received considerable attention as researchers and theorists have enthusiastically embraced an integration of meaning-focused and form-focused instruction in the $\mathbf{L 2}$ classroom. Therefore, the present paper is an attempt to delve deeply into elucidating different taxonomies subsumed under the specious polarization of Focus on Form (FoF) and Focus on Forms (FoFs). It then offers the possible rationale behind the integration of FoFs into meaning-centered and communicative classes. The article also elaborates upon the methodological implications underpinning reactive vs. preemptive focus on FoF. Analogous to other approaches to SLA, some practical, socioeconomical, and cultural criticisms were raised against FoF. The researchers conclude that the developed myth about the FoF and FoFs polarization should be treated cautiously. They also propose a complementary-compensatory approach to teaching FoF and FoFs.
\end{abstract}

Index Terms-FoF, FoFs, reactive and preemptive FoF

\section{INTRODUCTION}

A substantial body of research, culminating in Norris and Ortega's (2000) meta-analysis, corroborates the growing consensus that explicit instruction was significantly more effective than implicit instruction and that the effects of Form Focus Instruction(FFI) were durable (Mitchell, 2000; Ellis, 2002; Williams, 2001, 2005). In recent years focus on form (FonF) has gained great momentum in second language (L2) literature in the light of classroom research that advocates the need for instructional interventions to help learners gain higher levels of proficiency in L2 (Doughty \& Williams, 1998a; Long \& Robinson, 1998;Norris \& Ortega, 2000; Williams, 2005; Ellis et al., 2001; Ellis, 2006 ). Seemingly, when left to their own resources, 'learners do not very readily infer knowledge of the language system from their communicative activities' (Widdowson, 1990, p. 161). Consequently, some form of instructional focus on linguistic features may be required to destabilize learners' interlanguage (Ellis, 2006). FonF has evolved from Long's instructional treatment that 'overtly draws students' attention to linguistic elements as they arise incidentally in lessons whose overriding focus is on meaning or communication' (Long, 1991, pp. 45-46) into such tasks as processing instruction (VanPatten, 2002), textual enhancement (Sharwood Smith, 1993; Harley, 1998; White, 1998), and linguistic or grammar-problem solving activities (Willis, 1996; Ellis, 1997; Thornbury, 2001; Bourke, 2004). Although literature is replete with various interpretations and taxonomies of FonF, the key tenet of FonF instruction remains: 'meaning and use must already be evident to the learner at the time that attention is drawn to the linguistic apparatus needed to get the meaning across' (Doughty and Williams, 1998a, p. 4).

The present article is an attempt to elaborate on FoF/s taxonomies and illuminate some of the key concepts and tenants of FoF/s. It also aims to present the prospective readers with some of the methodological procedures as how to approach FoF/s in the communicative classes. The article also explicates some of the inherent criticisms raised against FoF. It then goes on to reconcile the two oft-cited extremes, i.e., focus on form and focus on forms. It is finally concluded that a complementary-compensatory approach should be pursued to tap upon both fluency and accuracy.

\section{FOCUS ON FORM/S DEFINITIONS AND TAXONOMIES}

The term focus on form has since been stretched beyond the meaning that Long (1991) originally assigned to it. Doughty and Williams (1998a), for instance, highlight that "there is considerable variation in how the term 'focus on form' is understood and used" (p.5). Thus FFI refers to a host of activities that diverge from one another in important ways and a number of elements must be regarded such as: (a) the continuum of implicit versus explicit FFI, with formal, rule based instruction at one end, and embedding of the target structure in authentic discourse at the other; (b) the timing of FFI during the lesson; (c) the teacher's role and intention; (d) task-based FFI; (e) the existence of input enhancement 
during communicative lessons designed to draw learner attention to the form; and (f) out-based FFI ( Nassaji \& Fotos, 2007, pp. 11-12). As to all these dimensions of FFI, various FFI taxonomies and definitions are in order (Long, 1991; Williams, 1995, 2005; Doughty and Williams, 1998a; 1998b; Lightbown, 1998; Long and Robinson, 1998; Nassaji, 1999; Ellis et al., 2002).

One of the first classifications which has had a great impact on our understanding of FFI is the demarcation made by Long (1991) between focus on form (FoF) and focus on forms (FoFs). Long (1991) conceptualized the need to incorporate form focused instruction into meaning-oriented communicative language teaching with the term "focus on form." FoFs, as defined by Long (1991; 1996; 2000), is predicated on the assumption that linguistic elements are preselected and presented to learners in an isolated and decontextualized manner like traditional structural and synthetic approaches to language teaching (Wilkins, 1978) in which language is broken down into discrete elements and is then presented to them in an intensive fashion. Thus, in focus on forms instruction the primary focus of attention is on the form that is being targeted. A quintessential example of a focus-on-forms lesson is one conducted by means of 'PPP' (i.e. a three stage lesson typical in Situational Language Teaching encompassing the presentation of a grammatical structure, its practice in controlled drills and the provision of opportunities to produce it freely) (Ellis et. al, 2002). This is in stark contrast with FoF in which the primary focus of attention is on meaning and communication and involves drawing learner's attention to linguistic forms 'as they arise incidentally in lessons whose overriding focus is on meaning or communication' (Long, 1991,p.46). For example, students may be asked to perform an opinion-gap task and in the course of doing so have their attention drawn to one or more linguistic forms which are necessary to perform the activity. Long (2000) recapitulates that FoF instruction is prior to FoFs in that FoF is learner-centered, is compatible with learner's internal syllabus, and is need-sensitive.

In a nutshell, Long (1991) propounds that focus on form

1. occurs in discourse that is primarily meaning centered

2. is observable (i.e., occurs interactionally)

3. is incidental (i.e., is not preplanned)

4. is transitory

5. is extensive (i.e., several different forms are attended to in the context of a single lesson)

Ellis et al. (2001a) pinpointed that this definition is not entirely in line with that of other researchers. Doughty and Williams (1998b), for example, regard focus on form as including planned lessons directed at teaching specific linguistic features, providing that the features are taught in context through communicative activities. Doughty and Williams' definition of focus on form incorporates criteria (1), (2), and (4). However, it differs from the above definition with regard to criteria (3) and (5); that is, planned focus on form obviously does not occur incidentally, and it is intensive rather than extensive (i.e., it involves repeated attention to a single form rather than one-shot treatments of multiple forms).

Long (1991) and Long \& Robinson (1998) expound that both focus on forms and focus on meaning instruction are worthwhile, and should complement rather than exclude each other. Focus on form instruction, in their view, maintains a balance between the two by calling on teachers and learners to attend to form when necessary, yet within a communicative classroom environment. However, Long (1991) and Long\& Robinson (1998) do not guarantee that focus on form instruction will lead to a specific level of L2 grammatical development within a certain time frame, presumably because of factors related to quality of instruction, intensity of instruction, and the stages of morphosyntactic development through which L2 learners must pass (Lightbown and Spada, 1999).

As mentioned earlier, Long (1991) and Long and Robinson (1998) conceptualized FoF mainly as reactive responses to communication problems, occurring after the event, Doughty and Williams (1998b), moreover, recommended that FoF can also be achieved proactively; that is, the teacher can also plan in advance to introduce FoF.

Ellis (2001) contends that although the reactive/proactive dichotomy is beneficial as both constitute occasions where learners are invited to FoF while their primary attention is on meaning, the proactive vantage point does not fulfill the incidental characteristic of FoF as posited in Long's (1991) original definition. Therefore, proactive FoF can contribute to repeated opportunities for attention to a pre-ordained language form or intensive instruction whereas incidental FoF, elaborated below, results in extensive instruction in that a welter of linguistic forms including grammatical, lexical, phonological, and pragmatic forms may compete for leaner attention.

To alleviate the confusion triggered by some of these dichotomies, Ellis et al. (2002) distinguish among three types of FFI, namely FoFs, Planned FoF, and incidental FoF.

TABLE 1

TYPES OF FORM-BASED INSTRUCTION

\begin{tabular}{llcc}
\hline Type & Syllabus & Primary focus & Distribution \\
\hline 1. Focus-on-forms & Structural & Form & Intensive \\
2. Planned focus-on-form & Task-based & Meaning & Intensive \\
3. Incidental focus-on-form & Task-based & Meaning & Extensive \\
\hline
\end{tabular}

Ellis et al. (2002) define focus on forms as the pre-selection of specific features based on a linguistic and grammatical syllabus and the intensive and systematic treatment of those features. Hence, the primary focus of attention is on the form. On the contrary, they postulate that in FoF instruction the primary focus of attention is on meaning. They 
further explicate that the attention to form arises out of meaning-centered activity derived from the performance of a communicative task such as information gap task.

Fotos and Nassaji (2007) pinpoint that Ellis (2001) has characterized FoFs as instruction that encompassed preselected forms presented to the learners either implicitly or explicitly. They point out that explicit instruction can be achieved through teaching rules, while implicit teaching is done through exercises which allow the learners to infer the rules such as structured input and production practice, thus creating a FFI continuum ranging from structure-based instruction to communicative lessons including the target form.

As shown in Table 1, focus-on-form instruction can subsume planned focus-on-form and incidental focus-on-form. Ellis et al. (2002) define the former as a kind of instruction which involves the use of focused tasks, i.e. "communicative tasks that have been designed to elicit the use of a specific linguistic form in the context of meaningcentered language use" (p.420). So, in this regard, the FoF is preordained with the difference that the treatment occurs while the learner's subliminal attention on form and primary attention is on meaning (for example, communicative input containing the form, textual enhancement, or communicative tasks using the form, Fotos and Nassaji, 2007). A same-ordifferent task could also be used to present pairs of pictures where the learners are required to use 'on' and 'in' (the target forms) so as to determine whether the pictures are the same or different.

It is concluded that this type of focus-on-form instruction is similar to focus-on-forms instruction in that a specific form is pre-selected for treatment but it differs from it in two key respects. Firstly, the attention to form occurs in interaction where the primary focus is on meaning. Secondly, the learners are not made aware that a specific form is being targeted and thus are expected to function primarily as 'language users' rather than as 'learners' when they perform the task (Ellis et al., 2002).

Elis et al. (2001b) expound that incidental focus-on-form involves the use of unfocused tasks, i.e. communicative tasks designed to elicit general samples of the language rather than specific forms. They argue that unfocused tasks can be performed without any attention to form. However, it is also possible that the students and teacher will elect to incidentally attend to various forms while performing the task. In this case, attention to form is extensive rather than intensive - that is, many different forms are likely to be treated briefly rather than a single form addressed many times. It is like a spiral not a linear gradation and presentation of language materials. For example, while performing an opinion-gap task, students might make a number of different errors which the teacher corrects or students might feel the need to ask the teacher about a particular form, such as the meaning of a key word they do not know. Both types of focus on form require the use of a communicative task. In the case of planned focus-on-form, the teacher elects to use a task to target a specific linguistic feature and this then influences how the task is performed in the classroom. In the case of incidental focus on form, the forms attended to are not pre-determined but arise naturally out of the performance of the task. Even when the focus on form is planned, incidental attention to a range of forms in addition to the targeted form can occur.

Moreover, incidental focus on form (Ellis, 2001) takes place spontaneously, without prior intention, during meaningfocused activities and targets a host of linguistic items. The unit of analysis in studies of incidental focus on form has been what Ellis et al. (2001a) have termed the Focus on Form Episode (FFE), which includes all discourse pertaining to the specific linguistic structure that is the focus of attention. Example 1, taken from Ellis et al. (2001a, p. 300), illustrates an FFE in which a student asks a question about the meaning of a word in a discussion activity. All of these utterances pertain to the linguistic structure spoil; consequently, they constitute one FFE.

\section{Example 1}

$\mathrm{S}$ : excuse me, T, what's spoil means?

$\mathrm{T}:$ spoil means $=$

$\mathrm{S}:=$ spoil

$\mathrm{T}$ : if you are my child

S: $\mathrm{mhm}$

$\mathrm{T}$ : and you keep saying give me, give me sweets, give me money, give me a football, let me watch TV, and I say yes all the time, yes, I spoil you. I give you too much because you always get what you want.

S: ah, ah

T: so

S: they spoil them, mm, they always get whatever

Fotos and Nassaji (2007) point out that the incidental FoF is very similar to Long's (1991) and Long and Robinson's (1998) definition of FoF. However, it is also different in that Ellis' notion of FoF can involve explicit attention to form as well as responses to anticipated 'need', in addition to communicative 'problems'. Alternatively, Nassaji (1999) has conceptualized that focus on form can be actualized in the language classrooms through both process and design. The former refers to FoF which is created incidentally when both the teacher and the learner's attention is on processing meaning whereas the latter occurs intentionally through designing communicative grammar tasks in which attention to linguistic form plays an indispensable role in order to complete the task.

\section{THE RATIONALE FOR FOCUS ON FORM}


The interest in focus on form is partly triggered from the suggestion that it can empower learners to develop linguistic accuracy because it provides the conditions for interlanguage restructuring to take place (Doughty, 2001; Long and Robinson, 1998). Loewen (2003), for example, argues that focus on form enables learners to take time out from a focus on meaning to notice linguistic items in the input, thereby overcoming a potential obstacle of purely meaning-focused lessons in which linguistic forms may go unnoticed. Such noticing, Schmidt (1990, 1995, 2001) argues, is necessary for L2 learning. Not only does focus on form provide learners with an opportunity to notice linguistic items, but it may also help them to 'notice the gap' (Schmidt and Frota, 1986) between models of the target language and their own language production. Moreover, focus on form provides opportunities for 'pushed output' which enhances learners' competence through the need to express themselves in language that is accurate and appropriate (Swain, 1995, 2000; Swain and Lapkin, 1995). For these reasons, focus on form is seen as potentially beneficial for L2 learners.

It is also noted that the call for FoF is often inspired by learner's problems or difficulties (Williams, 2005, p. 674), usually culminating in a breakdown in communication. The problematic linguistic features were embedded into instructional focus to assist learners get back on track. In this way, FoF is compatible with the communicative approaches (Muranoi, 2000; Basturkmen et al., 2004; Nunan, 2004), particularly when learners are required to stretch their interlanguage resources to meet the communicative task demands. Vanpatten (2002) argues that form and meaning compete with each other in learners with limited L2 processing capacity; therefore, they experience difficulty in simultaneously attending to form and meaning. VanPatten (2002) further states that these learners will prioritize meaning over form when performing communicative activities. VanPatten (2002) suggests that one way to teach grammar communicatively is through processing input or what he called processing instruction. In this approach an initial exposure to explicit instruction is interwoven with a series of input processing activities, consisting mainly of tasks that encourage the comprehension of the target structure rather than its production .These activities have been suggested to help learners to create form meaning connections in input and hence process grammar for meaning (Lee \& VanPatten, 1995). Due to the explicit focus on form component of this approach, some researchers have equated it with Long's focus on forms (e.g., Sheen, 2002). VanPatten (2002), however, argues that since the aim of this approach is "to assist the learner in making form-meaning connections during input processing; it is more appropriate to view it as a type of focus on form" (p. 764).

The need for FoF becomes even more significant 'when learners have acquired some communicative ability and when they run the risk of fossilizing' (Ellis, 2003, p. 78). The very nature of FoF as learner-centered allows for a nonlinear learning process to take place in the L2classroom, and for individual learners to progress according to a developmental sequence that is not necessarily in step with explicit instruction. Alternatively, Williams (1999) points out that the findings of a wide range of immersion and naturalistic acquisition studies suggest that when second language learning is merely experiential and focused on communicative success, some linguistic features do not develop to target like accuracy. This occurs in spite of years of meaningful, comprehensible input and opportunities for interaction. Long (1996) took the view that instruction that includes focus on form has at least two advantages over purely meaning-focused instruction: It can increase the salience of positive evidence, and it can provide often essential negative evidence, in the form of direct or indirect negative feedback. Taken together, these theoretical explanations provide a compelling rationale for the inclusion of FFI in second/foreign language curricula.

\section{Methodological Implications of FFI: REACtive VS. PREEMPTIVE FoF}

In this section, we will briefly elaborate on some of the methodological procedures as how to deal with FFI. Another dichotomy posited by Long \& Robinson (1998) and elaborated by Ellis et al. (2001b) is between reactive and preemptive focus on form whether it is planned (proactive) or incidental. As the name signifies, reactive focus on form arises when learners produce an actual or a perceived erroneous utterance, which is then addressed usually by the teacher or by another learner. Thus, it supplies learners with negative evidence. As Long and Robinson suggest, this evidence can be explicit (e.g., the learner is told directly what the error is or is given metalingual information relating to the correct form) or implicit (e.g., the learner's deviant utterance is recast in the target language form). Doughty and Varela's(1998) study provided reactive focus on form of the implicit kind. There is a considerable literature on teachers' corrective feedback, including a number of descriptive studies (Lyster, 1998a, 1998b; Lyster \& Ranta, 1997; Oliver, 2000) and a review (Seedhouse, 1997). These studies show that corrective feedback is common even in meaningfocused language instruction (such as that found in immersion classrooms); that teachers typically favor indirect, implicit correction rather than direct, explicit correction; and that learners often do not uptake correction (i.e., they make no attempt to produce the correct utterance that has been modeled for them).

Ellis et al. (2001b) explicate that reactive focus on form occurs in episodes that involve negotiation. Pica (1992), for example, defines negotiation as applying "to those interactions in which learners and their interlocutors adjust their speech phonologically, lexically, and morphosyntactically to resolve difficulties in mutual understanding that impede the course of their communication" (p. 200). To put it simply, negotiation is problem-oriented in that it arises as a response to a communicative problem. Pica (1992) proposes two types of negotiation, namely negotiation of meaning and negotiation of form. The former is entirely conversational and communicative in orientation, as it is directed at enabling the participants to achieve mutual understanding in order for communication to proceed. Example 2 below 
demonstrates this type of negotiation. The latter, however, is didactic in orientation, as it is targeted at boosting accuracy and precision when no problem of understanding has arisen. As Lyster and Ranta (1997) point out, both types of negotiation occur in meaning-focused instruction (e.g., immersion classrooms), and both involve corrective feedback and thus are reactive in nature.

Like reactive focus on form, preemptive focus on form is problem-oriented. However, the nature of the problem differs. While reactive focus on form entails negotiation and is stimulated by something problematic that an interactant has said or written, preemptive focus on form involves the teacher or learner initiating attention to form even though no actual problem in production has arisen. In other words, reactive focus on form addresses a performance problem (which may or may not reflect a competence problem) whereas preemptive focus on form addresses an actual or a perceived gap in the students' knowledge. The type of discourse that arises in preemptive focus on form differs from that found in reactive focus on form. Thus, whereas the latter takes the form of sequences involving a trigger, an indicator of a problem, and a resolution (Varonis \& Gass, 1985; see Example 2), the former consists typically of exchanges involving a query and response.

\section{A. Reactive Focus on Form: Conversational vs. Didactic Focus-on-form}

The linguistic errors that students make during a communicative activity may or may not block the communication. In Example 2 the student's error breakdowns the communication, resulting in the teacher addressing this by negotiating meaning. Student 1, whose name is Bess, wants to tell the teacher that her group has given itself the name 'Best Group'. However, the teacher mishears and thinks the name is 'Bess'Group'. This results in student 1 paying closer attention to her pronunciation in order to clarify the name.

\section{Example 2: Conversational focus-on-form (request for confirmation)}

$\mathrm{S}$ : my group has a name

$\mathrm{T}$ : what name?

S1: best

T: Bess' group?

S1: best

T: oh, best, okay

S2: best

T: best, not group three, the best, that's a lovely name (adapted from Ellis et al., 2002, pp.424)

In Example 3, two students are performing a role play with student 1 acting as a guest and student 2 as a hotel receptionist. The teacher fails to understand Student's 2 utterance and consequently requests clarification ('What?') causing the student to reformulate it using a contraction (I'll) in place of the original full form (will).

\section{Example 3: Conversational focus-on-form (request for clarification)}

$\mathrm{S} 1$ : I'm look for a room, or

S2: I will take you

T: what?

S2: I'll take you (adapted from Ellis et al., 2002, p.424)

Ellis et al. (2002) believe that both salience and communicative need, which are evident in conversational focus-onform, constitute the ideal conditions for noticing and acquisition to take place. Teachers can negotiate meaning conversationally using either requests for confirmation or requests for clarification. They elaborate that a request for confirmation typically involves the teacher repeating the problematic utterance with or without reformulating it. In Example 2, the teacher asks the student to confirm that she has heard the name of the group correctly. A request for clarification is typically used when the teacher does not have a clear idea of what the student has said. It is performed formulaically by means of expressions such as 'Sorry?' and 'Could you say that again?' There is a major difference between these two ways of accomplishing meaning negotiation. In the case of a request for confirmation, students only need to reformulate their own utterances if it is clear that the teacher has not understood correctly. In contrast, a request for clarification places the responsibility on the student for dealing with the problem and is more likely to lead to a reformulation of the problem utterance as in Example 3.

Sometimes, however, a student error does not result in communication breakdown but the teacher wants to emphasize language accuracy. In Example 3, the student leaves out the definite article 'the'. The teacher has no difficulty understanding him but focuses attention on the error by correcting the utterance. The focus-on-form episode that results from this type of error treatment constitutes a kind of pedagogic 'time-out' from meaning-focused communication and for this reason can be considered 'didactic'. It involves a 'negotiation of form' rather than a 'negotiation of meaning'. Ellis et al. (1999) found that didactic focus-on-form was far more common than conversational in communicative ESL lessons involving adult learners.

\section{Example 4: Didactic focus-on-form}

$\mathrm{S}$ : I was in pub

(2.0)

$\mathrm{S}$ : I was in pub

$\mathrm{T}$ : in the pub?

S: yeah and I was drinking beer (adapted from Ellis et al., 2002, p.425) 


\section{B. Pre-emptive Focus on Form}

Pre-emptive focus on form can be either student-initiated or teacher-initiated. Like reactive focus-on-form, preemptive focus on form can be conversational (i.e. motivated by communicative need) or didactic. Student pre-emptive focus-on-form is typically initiated by means of a query that the student addresses to the teacher. The advantage of student-initiated preemptive focus-on-form is that it addresses gaps in the students' linguistic knowledge which can be presumed to be significant to them (for otherwise why would they ask?) and which they are therefore strongly motivated to try to fill. A disadvantage of student-initiated attention to form, however, is that it can detract from the communicative activity. This is one reason why teachers may decline to answer a student query (Ellis et al., 2002)

\section{Example 5: Student-initiated pre-emptive focus-on-form}

$\mathrm{S}$ : How do you pronounce this word?

T: Omniscient

S: Omnis...cient

$\mathrm{T}$ : Omniscient

S: Omniscient, thank you very much.

T: Sure

Ellis et al. (2001b) argue that teachers also interrupt the flow of a communicative activity to draw student's attention to a specific form. In so doing they are electing to disrupt the meaning-centeredness of an activity, presumably because it is predicated on the assumption that the form in question will be problematic to the students in some way. Teacherinitiated focus on form is initiated either by a query directed at the students or by an advisory statement.

\section{Example 6: Teacher-initiated focus-on-form}

$\mathrm{T}: \mathrm{M}$ has an alibi

(3.0)

$\mathrm{T}$ : another name for girlfriend?

(laughter)

$\mathrm{T}$ : an alibi is a reason you have for not being at the bank robbery (.) okay (.) not being at the bank robbery (adapted from Ellis et al., 2002, pp.428-429)

It is well documented in the literature on FFI that two sides of the continuum, that is, FoF and FoFs, have yielded great results in fostering language abilities. However, many questions still seek clear-cut answers. These include:

1. To what extent should teachers emphasize focus-on-form?

It is not quite vivid that how much teachers should put emphasis on focus-on-form since a communicative language lesson has a dual objective-to foster students' fluency and accuracy. Although it is proposed that form and meaning may compete, the two should be in harmony with each other not making extremes. They should not be in a complementary distribution, that is, the existence of one excludes the other. So it is highly recommended that teachers develop tasks to focus on both meaning and form simultaneously, and the two should complement each other.

2. To what extent should focus-on-form be conversational or didactic?

It is pertinent to the preceding. The classroom should tap upon both of them. It should be noted that language is not divisible, so both form and meaning should be incorporated both in EFL and ESL communicative language classrooms. It is, however, undeniable that teachers can prioritize meaning over form or the other way round, but they are recommended not to exclude either.

3. To what extent should teachers pre-empt attention to form during a communicative task?

Ellis et al. (2002) argue that the pre-emption of form during a communicative activity disrupts the class to focus on meaning. We, however, postulate that the pre-emption of some of those linguistic features especially pronunciation prevents fossilization. Our experience also justifies that some students really like to be corrected by their teachers even during communicative activities. These students express that when their mistakes or errors are corrected, it indicates that teachers pay close attention to them not simply looking at them.

4. To what extent should student-initiated pre-emptive focus-on-form be fostered?

While Ellis et al. (2001b) in a seminal article concluded that in 12-hours of meaning focused instruction, there were as many preemptive focus-on-form episodes (FFEs) as reactive FFEs, Baleghizadeh (2010) found that in 10 hours of meaning-focused instruction there were few instances of preemptive focus-o- form. The divergent results could be attributed to the sociocultural settings. Comparing the divergent results of these two studies, we suggest that more studies should be documented in the literature so that teachers will stand in a better position to make judgments.

\section{CRITICISMS OF FOCUS ON FORM INSTRUCTION}

While these studies and many others have provided us with valuable insights (Norris and Ortega, 2000; Ellis at al., 2001b; Doughty and Varela, 1998; Williams, 1999; 2001; Basturkmen et al., 2004; Murani, 2000; Loewen, 2003), they all have taken place in settings that appear to be well-funded, adequately supplied with teaching and learning materials, and generally free of classroom discipline problems. Moreover, most studies of focus on form instruction have taken place in a few countries, namely the United States, New Zealand, and Japan (Poole and Sheorey, 2002). It is apparent from the literature on FoF that not a single empirical study can be found that took place in a setting in which classes 
were overcrowded, up-to-date materials were generally not available, and teachers received less than adequate training in language skills and pedagogy (Poole, 2005). In like manner, no study supporting focus on form instruction appears to have taken place in a developing country, where the socioeconomic, political, and pedagogical realities may differ significantly from those in more developed countries. Thus, instructors and curricula designers in many settings have little information to judge whether or not focus on form instruction would be appropriate in their programs.

Although focus on form instruction has yet to be investigated in many settings, it is not viable in many circumstances due to curricular constraints. In particular, in many secondary and university language programs, teachers are obligated to teach certain forms in a specific order by using government-mandated materials. In Iran, for example, junior high school and high school English textbooks, which are not at all meaning-centered, are mandated by the Ministry of Education where teachers have little say in designing the curriculum, choosing the materials and textbooks.

Another inherent problem with focus on form instruction lies in the practical side, specifically, class size. Focus on form instruction, in Long (1991) and Long and Robinson's (1998) conception, seems optimally suited to classrooms that are small enough to enable instructors to verbally address their students' problematic forms, presumably via classroom discussion, Q/A sessions, and impromptu and planned public speaking events. As far as writing is concerned, such a classroom would need to allow teachers to frequently evaluate students' writing, presumably in the form of essays, in-class writing tasks, and journals/diaries. Likewise, small classes would be needed for students to have significant amounts of peer interaction both orally and in written form. In many settings, however, classes are large, and individual attention and student-student interaction is not possible (Poole, 2005).

Quite in par with Poole (2005) and others, we cogently argue that in addition to curricular problems, many English language teachers lack a high level of L2 oral proficiency and do not have opportunities for developing it. However, Long (1991) and Long and Robinson's (1998) conception of focus on form instruction mandates teachers to have native-like or near native-like competence fluency, more specifically, in oral situations where they would need to be able to spontaneously recognize students' form-based errors and provide them with the correct feedback. Butler (2004), for example, reports that elementary school EFL teachers in Japan had low self-ratings of their own L2 proficiency, particularly in the area of oral grammar. Similarly, Yu (2001) illustrates that similar levels of low-proficiency are prevalent among Chinese EFL teachers who feel that their only option is the grammar-translation method: "Quite a number of teachers know only some basic English grammar and vocabulary. For them the grammar-translation method is the most acceptable because they can basically teach English in Chinese" (p. 197). Teaching English through the native language is commonplace in many settings not because of any objections against using English, but simply because of low L2 proficiency on the part of teachers.

Last but not least, focus on form instruction is not viable in some countries due to cultural variables. Focus on form is highly individualistic in that errors are frequently, although not exclusively, addressed on an individual basis. Hofstede (1986) suggests that individualistic societies tend to produce more individualistic teaching approaches; however, collectivist societies, which tend to focus more on the general good of all students, may find focus on form at odds with their cultural values. Put it succinctly, successful focus on form instruction would need to take place in a cultural atmosphere that allows students to actively participate in daily activities. Thus, administrators, teachers, parents, and students would need to feel some degree of comfort with letting students be active participants-and sometimes leaders - in the content and manner in which they study.

\section{THE RECONCILIATION NOT POLARIZATION OF FOCUS ON FORM \& FOCUS ON FORMS}

It sounds quite indispensable to conceive that the dichotomy conceptualized and encapsulated by Long (1991) is much theoretical in nature. Put cogently, a focus on form is appreciated as being compatible with currently-accepted theories of SLA, while a focus on forms is stigmatized as being incompatible with them. Sheen (2003) depreciates this polarization contending that this stigmatization results purely from theorizing on the nature of SLA, and not on the rigorous and reliable long-term trialing of these options in the classroom settings. Sheen further argues that the myth that a focus on form is more conducive to learning than its counterpart is attaining more credibility due to its great embrace by applied linguists. Sheen (2003) justifies his position by asserting that further evidence of the unjustified bolstering of the claims of a focus on form at the expense of the other is provided in Norris and Ortega's (2000) metaanalysis. It is, however, surprising that in their study, Norris and Ortega excluded all pre-1980 comparative studies. Speciously, they concluded that "....... focus on form and focus on forms are equally effective” (p. 501). Hadn't they excluded those studies, the pendulum would have swung in favor of focus on forms.

In a nutshell, we highly recommend teachers and researchers to have a complementary-compensatory approach towards FoF and FoFs. Both approaches sound viable in some special settings as argued before.

\section{CONCLUSION}

The present article reviewed the most important FFI dichotomies, offering some methodological procedures for teachers and demystifying some of the misconceptions which have long confused teachers and researchers. We also concluded that there should have been a call for an integration of meaning-focused and form-focused instruction as a complementary-compensatory approach in the EFL/ESL classrooms in order to promote both learners' fluency and 
accuracy. Teachers and researchers should not stigmatize a focus on forms approach since it has proven to be equally effective in fostering language abilities. However, we strongly suggest that future research does need to take place in more diverse cultural and socioeconomic circumstances in order to determine whether or not focus on form instruction is appropriate for different groups of learners, not solely focusing on well-funded schools, adequately supplied with teaching and learning materials, and generally free of classroom discipline problems. If research on focus on form instruction does not take into consideration the realities of classrooms, then it will not bear little relevance to large number of teachers and learners. In the interim, however, teachers, teacher trainers, and administrators should continue to read the literature on focus on form instruction; yet, they should not decide on its merits solely on the basis of what professional journals say, but rather should give equal attention to their perceptions of their local instructional needs and realities.

\section{REFERENCES}

[1] Baleghizadeh, S. (2010). Focus on form in an EFL communicative classroom. Novitas-ROYAL (Research on Youth and Language), 4 (1), 119-128.

[2] Basturkmen, H., Loewen, S. \& Ellis, R. (2004). Teachers' stated beliefs about incidental focus on form and their classroom practices. Applied Linguistics, 25(2), 243-272.

[3] Bourke, J. (2004). Towards the design of a problem-solving program of instruction for teaching English grammar to secondarylevel ESL students. Journal of Applied Research in Education, 8(1), 104-122.

[4] Butler, Y. (2004). What level of English proficiency do elementary school teachers need to attain to teach EFL? Case studies from Korea, Taiwan, and Japan. TESOL Quarterly, 38 (2), 245-278.

[5] Doughty, C. (2001). Cognitive underpinnings of focus on form. In Robinson, P., editor, Cognition and second language instruction (pp. 206-57), Cambridge: Cambridge University Press.

[6] Doughty, C., \& Varela, E. (1998). Communicative focus on form. In Doughty, C. \& Williams, j. (Eds.), Focus on form in classroom second language acquisition (pp. 114-138). Cambridge: Cambridge University Press.

[7] Doughty, C. \& Williams, J. (1998a). Issues and terminology. In Doughty, C. \& Williams, J. (Eds.), Focus on form in classroom second language acquisition (pp. 1-11). Cambridge: Cambridge University Press.

[8] Doughty, C. \& Williams, J. (1998b). Pedagogical choices in focus on form. In Doughty, C. \& Williams, J. (Eds.), Focus on form in classroom second language acquisition (pp. 197-261). Cambridge: Cambridge University Press.

[9] Ellis, R. (1997). Second language acquisition. Oxford: Oxford University Press.

[10] Ellis, R. (2001). Introduction: Investigating form-focused instruction. Language Learning, 51, Supplement 1, 1-46.

[11] Ellis, R. (2002). Does form-focused instruction affect the acquisition of implicit knowledge? A review of the research. Studies in Second Language Acquisition 24, 223-236.

[12] Ellis, R. (2003). Designing a task-based syllabus. RELC Journal 34(1), 64-81.

[13] Ellis, R. (2006). Current issues in the teaching of grammar: An SLA perspective. TESOL Quarterly 40(1), 83-108.

[14] Ellis, R., Loewen, S., \& Basturkmen, S. (1999). Focusing on Form in the Classroom (Technical Report). Institute of Language Teaching and Learning, University of Auckland.

[15] Ellis, R., Basturkmen, H. and Loewen, S. (2001a). Learner uptake in communicative ESL lessons. Language Learning 51, 281318.

[16] Ellis, R., Basturkmen, H. and Loewen, S. (2001b). Preemptive focus on form in the ESL Classroom. TESOL Quarterly 35 , 407-32.

[17] Ellis, R., Basturkmen, H. and Loewen, S. (2002). Doing focus on form. System, 30, 419-432.

[18] Fotos, S. , \& Nassaji, H. (2007). Issues in form-focused instruction and teacher education. In Fotos, S. , \& Nassaji, H. (Eds) Form-focused Instruction and Teacher Education: Studies in Honor of Rod Ellis(pp. 7-15). Oxford, Oxford University Press.

[19] Harley, B. (1998). The role of focus-on-form tasks in promoting child L2 acquisition. In Doughty, C \& Williams, J. (Eds.), Focus on form in classroom second language acquisition (pp. 156-173). Cambridge: Cambridge University Press.

[20] Hofstede, G. (1986). Cultural differences in teaching and learning. International Journal of Intercultural Relations, 10, 301320

[21] Lee, J., \& VanPatten, B. (1995). Making communicative language teaching happen. San Francisco: McGraw-Hill.

[22] Lightbown, P. (1998). The importance of timing in focus on form. In Doughty, C. and Williams, J.(Eds), Focus on form in classroom second language acquisition, Cambridge: Cambridge University Press, 177-96.

[23] Lighbown, P. , \& Spada, N. (1999). How Languages Are Learned. Second Edition. Oxford: Oxford University Press.

[24] Loewen, S. (2003). Variation in the frequency and characteristics of incidental focus on form. Language Teaching Research, $7(3), 315-45$

[25] Long, M. H. (1991). Focus on form: A design feature in language teaching methodology. In de Bot, K., Ginsberg, R. \& Kramsch, C. (Eds.), Foreign language research in cross cultural perspective (pp. 39-52). Amsterdam: John Benjamins.

[26] Long, M. H. (1996). The role of the linguistic environment in second language acquisition. In Ritchie, W.C. \& Bhatia, T.K. (Eds.), Handbook of second language acquisition (pp. 413-468). San Diego, CA: Academic Press.

[27] Long, M.H. (2000). Focus on form in task-based language teaching. In Lambert, R. and Shohamy, E. (Eds). Language Policy and Pedagogy: Essays in Honor of A. Ronald Walton. Philadelphia: John Benjamins.

[28] Long, M.,\& Robinson, P. (1998). Theory, research and practice. In Doughty, C. \& Williams, J. (Eds.), Focus on form in classroom second language acquisition (pp. 15-41). Cambridge: Cambridge University Press.

[29] Lyster, R. (1998a). Negotiation of form, recasts, and explicit correction in relation to error types and learner repair in immersion classrooms. Language Learning, 48, 183-218.

[30] Lyster, R. (1998b). Recasts, repetition, and ambiguity in L2 classroom discourse. Studies in Second Language Acquisition, 20, $51-81$. 
[31] Lyster, R., \& Ranta, L. (1997). Corrective feedback and learner uptake: Negotiation of form in communicative classrooms. Studies in Second Language Acquisition, 19,37-66.

[32] Mitchell, R. (2000). Anniversary article: Applied linguistics and evidence-based classroom practice: The case of foreign language grammar pedagogy. Applied Linguistics 21(3), 281-303.

[33] Muranoi, H. (2000). Focus on form through interaction enhancement: Integrating formal instruction into a communicative task in ESL classrooms. Language Learning 50(4), 617-673.

[34] Nassaji, H. (1999). Towards integrating form-focused instruction and communicative interaction in the second language classroom: some pedagogical possibilities. Canadian Modern Language Review, 55(3), 385-402.

[35] Norris, J. M. \& Ortega, L. (2000). Effectiveness of L2 instruction: A research synthesis and quantitative meta-analysis. Language Learning 50(3), 417-528.

[36] Nunan, D. (2004). Task-based language teaching. Cambridge: Cambridge University Press.

[37] Oliver, R. (2000). Age differences in negotiation and feedback in classroom and pairwork. Language Learning, 50, $119-151$.

[38] Pica, T. (1992). The textual outcomes of native speaker-non-native speaker negotiation: What do they reveal about second language learning? In Kramsch, C. \& McConnell-Ginet, S. (Eds.), Text and context: Cross-disciplinary perspectives on language study (pp. 198-237). Lexington, MA: D. C. Heath.

[39] Poole, A.(2005). Focus on form instruction: Foundations, applications, and criticisms. Reading Matrix, 5(1), 47-56.

[40] Poole, A., \& Sheorey, R. (2002). Sophisticated noticing: Examination of an Indian professional's use of English. Indian Journal of Applied Linguistics, 28 (2), 121-136.

[41] Schmidt, R. (1990). The role of consciousness in second language learning. Applied Linguistics 11,129-158.

[42] Schmidt, R. (1995). Consciousness and foreign language learning: a tutorial on the role of attention and awareness in learning. In Schmidt, R., editor, Attention and awareness in foreign language learning, Hawaii: University of Hawaii Press, 1-63.

[43] Schmidt, R. (2001). Attention. In Robinson, P., editor, Cognition and second language instruction (pp.. 3-32), Cambridge: Cambridge University Press.

[44] Schmidt, R. and Frota, S. (1986). Developing basic conversational ability in a second language: a case study of an adult learner of Portuguese. In Day, R., editor, Talking to learn: conversation in a second language(pp. 237-326), Rowley, MA: Newbury House,

[45] Sharwood Smith, M. (1993). Input enhancement in instructed SLA: Theoretical bases. Studies in Second Language Acquisition, 15(2), 165-179.

[46] Seedhouse, P. (1997). The case of the missing "no": The relationship between pedagogy and interaction. Language Learning, 47, 547-583.

[47] Sheen, R. (2002). 'Focus on form' and 'focus on forms.' ELT Journal, 56, 303-304.

[48] Sheen, R. (2003). Focus on form-a myth in the making? ELT Journal, 57(3), 225-233.

[49] Swain, M. (1995). Three functions of output in second language learning. In Cook, G. and Seidhofer, B., editors, Principles and practice in the study of language (pp. 125-44), Oxford: Oxford University Press,.

[50] Swain, M. (2000). The output hypothesis and beyond: mediating acquisition through collaborative dialogue. In Lantolf, J., editor, Sociocultural theory and second language learning (pp. 97-114), Oxford: Oxford University Press.

[51] Swain, M. and Lapkin, S. (1995). Problems in output and the cognitive processes they generate: a step towards second language learning. Applied Linguistics 16, 371-91.

[52] Thornbury, S. (2001). Uncovering grammar. Oxford: Macmillan Heinemann English Language Teaching.

[53] VanPatten, B. (2002). Processing instruction: An update. Language Learning, 52(4), 755-803.

[54] Varonis, E., \& Gass, S. (1985). Non-native/non-native conversations: A model for negotiation of meaning. Applied Linguistics, 6, 71-90.

[55] White, J. (1998). Getting the learners' attention: A typographical input enhancement study. In Doughty, C. \& Williams, J. (Eds.), Focus on form in classroom second language acquisition (pp. 85-113). Cambridge: Cambridge University Press.

[56] Widdowson, H. G. (1990). Aspects of language teaching. Oxford: Oxford University Press.

[57] Wilkins, D. (1976). Notional syllabuses. Oxford: Oxford University Press.

[58] Williams, J. (1995). Focus on form in communicative language teaching: Research findings and the classroom teacher. TESOL Journal, 4(4), 12-16.

[59] Williams, J. (1999). Learner-generated attention to form. Language Learning 49, 583-625.

[60] Williams, J. (2001). The effectiveness of spontaneous attention to form. System, 29, 325.340.

[61] Williams, J. (2005). Form-focused instruction. In Hinkel E.(Ed.), Handbook of research in second language teaching and learning (pp. 671-692). Mahwah, NJ: Lawrence Erlbaum.

[62] Willis, J. (1996). A framework for task-based learning. London: Longman.

[63] Yu, L. (2001). Communicative language teaching in China: progress and resistance. TESOL Quarterly, 35 (1), 194-198.

Mohammad Khatib is Assistant Professor of TEFL at Allameh Tabataba'i University. He holds a Ph.D. in TEFL (Allameh Tabataba'i University, 1999), an M.A. and a B.A. in English Literature from Tehran University (1977 and 1972 respectively).

He began teaching at Allameh in 1981 and presently offers graduate and post-graduate courses in SLA Theories, Methodology, Literature in EFL Classes and English Literature.

His main areas of interest include SLA Theories, language learning strategies, culture and the integration of language and literature. He has published some articles on TEFL in Iranian Journals of Applied Linguistics. He has translated a book of short stories from famous writers of the world and published a guidebook on Shakespeare's selected sonnets. 


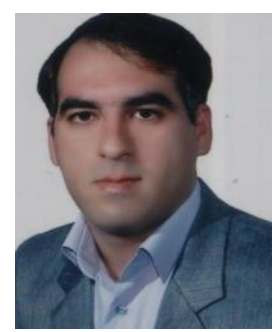

Ali Derakhshan is currently a $\mathrm{PhD}$ candidate majoring in TEFL at Allameh Tabataba'i University (ATU), Tehran, Iran. He received his M.A. in TEFL from University of Tehran, Iran in 2009. He has been a visiting lecturer at Sharif University of Technology and Allameh Tabataba'i University (ATU). He was also awarded the best national teacher in two consecutive years. He has coauthored 7 books and published some articles in international journals. His research interests are Language Assessment, Interlanguage Pragmatics Development \& Assessment, Syllabus Design, Teacher Education, Focus on Form/s, and MALL. Mr. Ali Derakhshan is the member of the Teaching English Language and Literature Society of Iran (TELLSI). 